\title{
Exploring Subconscious Bias
}

\author{
Kelvin Miu ${ }^{1}$, David Ranford ${ }^{1}$, Pavol Surda ${ }^{1}$, Claire Hopkins ${ }^{2}$, and Yakubu Karagama ${ }^{3}$ \\ ${ }^{1}$ Guy's and St Thomas' Hospitals NHS Trust \\ ${ }^{2}$ Guy's Hospital \\ ${ }^{3}$ Guy's and St Thomas' NHS Foundation Trust
}

September 24, 2021

\begin{abstract}
Background: Implicit biases involve subconscious associations that lead to a negative evaluation of a person based on irrelevant characteristics such as race or gender. This audit of management of patients who missed appointments investigates the presence of implicit bias in our unit. Methods: We retrospectively analysed discharge rates in 285 patients who missed an outpatient appointment between from 1/4/2020 at Guy's and St Thomas' Hospital. 285 patients were categorised into predefined ethnic categories: White British (WB) vs Black, Asian and Minority Ethnic (BAME) vs Other White (OW) after reading the patient's names. In the same fashion, we also assigned gender. Results: We did not find differences in discharge rates among self-reported ethnic and gender groups. Patients with WB sounding names were more likely to be discharged when compared to patients with BAME sounding names (35\% vs 58\%). Discharge rates between males and females did not differ. Conclusion: Our results suggest that implicit bias may play a role in decision-making whether to rebook a patient after missing an appointment.
\end{abstract}

\section{Hosted file}

Main Document - Exploring subconscious bias.docx available at https://authorea.com/users/ 435025/articles/538331-exploring-subconscious-bias

\section{Hosted file}

Table 1 - Exploring subconscious bias.docx available at https://authorea.com/users/435025/ articles/538331-exploring-subconscious-bias

\section{Hosted file}

Figure 1 - Exploring subconscious bias.docx available at https://authorea.com/users/435025/ articles/538331-exploring-subconscious-bias 